\title{
Problem of Personal Creative Development in Digital Education System
}

\author{
Chernov S.V. \\ Institute of Continuous Professional Education, \\ Moscow, Russia
}

\author{
Shapovalov V.I. \\ Sochi State University, \\ Sochi, Russia, \\ shapovalov_vi@mail.ru
}

\begin{abstract}
The article is devoted to the theoretical and methodological comprehension of characteristics of personal creative development in new conditions of a globalized world, one of logical consequences of them being the transition of modern education of Russia to digitalized technologies. Creative development is considered as the most important indicator of development of conscious, self-sufficient, self-asserting, spiritually mature, generally competitive personality. On the basis of the triadic dialectics developed in philosophical works of I. Kant, G.W.F. Hegel, V.S. Soloviev, and determined by Russian and Soviet philosopher A.F. Losev, the authors make an attempt to create a theoretical and methodological construct in the form of a triadic model for development of the problem of personal creative development. The model includes three directions of examining personal creative development: general philosophical reflection on the problem of personal creative development; ethical and esthetic, and cultural and historical analysis of the problem of personal creative development, and psychological and pedagogic study of personal creative development. In turn, every direction is presented as a corresponding categorical and conceptual triad of statements which describe a definite aspect of the study object - creative development of the personality. Versatility of a triad dialectical approach which includes key concepts for a complete description of individual aspects of the object under consideration, as well as the developed model of personal creative development allow revealing meaning, structure, content of the concept of personal creative development, and explicating them to the conditions of digital education. In the utilitarian aspect the model focuses on timely awareness of possible consequences which do not have analogs of technologic environment of digital education as an environment excluding creative activities. The result is possible degradation of the personality. Results of the theoretical study will help to determine practical reference points for considering risks of indiscriminate digitalization of educational environment in the formation and development of a creative personality.
\end{abstract}

Keywords-education, creative personality, personal creative development, digitalization of education, triadic dialectics, triadic model

\section{INTRODUCTION}

The problem of personal creative development has long occupied minds of thinkers, scientists, enlighteners of different directions. N.A. Berdyaev [1] regarded creativity as one of the key sighs of human spiritual life. In turn, according to N.A. Berdyaev [2]: «Spiritual life is not a reflection of any reality, it is reality itself». Spiritual life of a person is a real realization of Love, creation of Truth, and an increase in Beauty. Correspondingly, these three - Love, Truth, Beauty are universal ideas which simultaneously determine Spiritual Image of a person, a creative person who makes supreme orders of being, such as good, sublimity, beauty. In this case, a person manifests himself not just as an active individual, but as a creative constructive personality.

Studies in the problem of creative development of a person are associated with names of domestic Soviet scientists B.G. Ananiev [3] and P.Ya. Galperin [4], as well as modern scientists V.N. Markov, Yu.V. Sinyagin [5], S.V. Velichko [6], A.A. Rean [7]. A great contribution to the development of various aspects of this problem was made by foreign scientists, particularly, representatives of humanistic psychology A.H. Maslow [8], C.R. Rogers [9], and modern researchers M. Basadur and others [10], T. Dewett [11], G.A. Parker [12].

Since in modern realities education is (1) a "socially significant good", (2) ensures the integrity of society, (3) is one of the determining factors of national security of the state, (4) is the most important system providing progressive social, economic development, (5) is of special value for the personality formation [13], the problem of personal creative development has always been paid a special attention in the educational system. However, the level of modern psychological and pedagogical researches, as well as searches in the area of education philosophy, the subject of which is personal creative development, no longer fully corresponds to modern global challenges facing the modern person.

One of evident examples of these challenges is the recent pandemic of coronavirus, which resulted in emergent introduction of the system of digital education. M.S. Yanitsky [14] noted that the pandemic has revealed the range of problems: organizational, technical, structural, substantive, psychological and pedagogical, some of them have already been reported in the corresponding scientific literature. E. Toffler [15], T.V. Semenovskikh [16], E.P. Kabkova and others [17] include in this range also the problem, still 
unsolved, of clip thinking, the latter is being massively formed among active users of informative and digital technologies, and, hence, in the system of digital education.

At present, there occur works which regard various aspects of personal creative development related to the digitalization of modern education [18]. These works are of significant interest, since they attempt to determine the behavior manner of a person in new conditions, and the way of forming (changing, transforming) his mentality by new requirements to psychological readiness.

Today, under the conditions of rapidly changing environment, education requires students to analyze, assimilate, and productively use a large amount of information, independently make decisions on this base, frequently acting in conditions of probabilistic uncertainty. Due to these circumstances, the learner, in fact, becomes a creative organizer of his/her own activities in the "personality - environment" system, based on the personal creative potential.

Thus, on the one hand, digitalization performs an important function of realizing the learner's potential resource, complicating the external environment and making it more technical. A.V. Karpov [19] believes that creative abilities, as a cognitive component, are just the potential of the individual, while their realization can be provided only by external complicating conditions and new demands. On the other hand, according to many scientists and previous experience of mankind development, technocratized environment destructively acts on social adaption of a person, first of all, on his/her characteristics most sensitive to changes: morality, social responsibility, empathy, etc., i.e. everything in a person that can be destroyed, accidentally, by the digitalized education paradigm. Since creativity is one of main "indicators" of personal development, and the listed characteristics are its "engine", then the technocratized environment cannot give a complete realization of the creative potential of the individual.

As a result, according to N.V. Borisova [18], current "social and political transformations with the key word "digital" (revolution, era, economy, personality, education, etc.) create a new reality, a new ethics, and a new look at a person". In the author's opinion, such changes in the environment affecting all kinds of human activity and, above all, the development of human creative abilities naturally lead to the alteration of the system of personal value and meaning orientations in general, which determines the relevance of the problem research in the system of modern humanitarian knowledge.

\section{CATEGORY AND CONCEPT APPARATUS OF RESEARCH}

\section{A. Comparative analysis of "individual" and "personality" analysis}

Such an analysis is necessary to further identify the concept of "creative personality". N.A. Berdyaev [20] presents the image of human personality as "integrated spiritual moral and physical being", and, on this base, distinguishes between the categories of "individual" and "personality". Being a biological organism, the individual as an indivisible category is a part of nature, and, being a part of the genus, the individual is a sociologic category, due to this he/she is either subordinated to society as a part of the whole, or he/she rebels against society. But the individual "cannot oppose" to society as "the whole in itself". On the other hand, "personality is integrity and cannot be a part. Personality is not a part of nature and society, and cannot be thought of as a part in relation to any whole [21]. The individual as a natural being cannot create, but can give birth and preserve, produce and destroy, take away; but the individual cannot create, give and reward. The individual can require love and kindness towards himself/herself, but he/she is not able to give love and goodness to the other, and sacrifice himself/herself for this. The individual's concept of freedom as freedom from something borders on permissiveness, and his/her responsibility is limited by his/her basic instincts, physical needs, mental demands, social conditions and requirements. On the contrary, according to S.V. Chernov [21], freedom for the spiritually creative, perfectly moral personality is, above all, the burden of his/her responsibility in relation to the Other in the values of love and goodness, constructive labor and creativity.

So, "personality" as a "spiritual category" is defined as a direct spiritual relationship of a person with being, which is evidently manifested with providential, moral and creative activities of a person.

\section{B. Clarification of concepts of "creative personality" and "personal creative development"}

From the point of view of modern humanitarian knowledge, a creative personality is a person whose activities result in a qualitatively new, original, social and historic, unique discovery. What role does creativity plays in the educational system, and in what way is creativity associated with the process of knowledge assimilation? According to L.I. Bozhovich [22], the criterion of true knowledge assimilation is the student's knowledge transformation into a fact of the worldview, which alters the student's views on the surrounding and the attitude towards the latter in the direction of adequate perception of it and readiness for flexible adaptation to it (optimal use of one's competitive advantages) in order to obtain the best personally and socially significant result. Such criterion characterizes the personality as a creative one. However, the criterion requires certain clarifications.

According to the above, creativity is understood by the authors as a creative energy increasing the order of being, and, correspondingly, a creative activity is understood as the creation of the good, the sublime, the beautiful. On the contrary, the activity the product of which is destructive, low, ugly, extremely decreasing the order of being down to complete meon (non-being) is a destroying activity, opposed to a creative one. Consequently, a creative personality not only meets the criteria of novelty, originality and social significance of his/her products, but also the criterion of creating the good, the sublime, the beautiful, increasing the order of being.

Or, in other words, a creative personality is a subject creating and searching for perfection in the universal eidos of Love, Truth, Beauty.

In turn, personal creative development is understood as spiritually purposeful and morally justified formation of the personality whose spiritual potencies and searches will be aimed at creation of the good, the sublime, the beautiful, i.e. at 
an increase in spiritual being (spiritualizing of being). And this latter determines the meaning of the being of a person as a creating subject able to providentially think, morally grow, creatively develop, thereby providing the fullness of spiritual being.

Nowadays, a lot of research has appeared in the area of personal creative development, but these works do not concern essential and eidetic aspect of a creative developed person in that sense, content and meaning in which personal creativity is presented in this article.

\section{RESEARCH METHODS}

The methodological basis of the research is triadic dialectics developed in philosophical works of I. Kant [23], G.W.F. Hegel [24], V.S. Soloviev [24], and determined by the prominent Russian and Soviet philosopher A.F. Losev [26] as a method of construction (logical and dialectic constructing) of semantic, categorical and conceptual triads. The method of triadic dialectics, already applied in the researches of S.V. Chernov [27] and used in this research, suggests the construction of corresponding triads that reveal semantics and structure of the analyzed category by means of key concepts most fully describing individual aspects of the object under consideration, in our case - the problems of creative development of a person.

According to the structural and functional approach, creativity as a complex personal neoplasm should be considered in the system of the following theoretical and methodological categorical groups: (1) general philosophical reflection of the problem of personal creative development, (2) ethical and esthetic, cultural and historic analysis of the problem of personal creative development, and (3) psychological and pedagogical study of personal creative development. The present systemic and triadic idea $(1) \leftrightarrow(2) \leftrightarrow(3)$ was laid in the basis of the development of a triadic model of personal creative development. Practically, the triadic model can be considered as a project base for the creative development research, as a "bridge" between theoretical and methodological comprehension and understanding of the creative development of the personality, and its practical implementation in a real pedagogical activity.

\section{TRIADIC DIALECTICS OF RESEARCH OBJECT}

\section{A. General description of triadic model of creative development of personality}

The model (Table I) includes three groups of dialectic triads, and, accordingly, three reflexive and research levels: Group I (philosophical refection on the problem of personal creative development) includes the first, second and third triads $\left\{\alpha_{11} \alpha_{12} \alpha_{13}\right\}$; Group II (ethic and esthetic, and cultural and historic analysis of the problem of personal creative development) includes the fourth, fifth and sixth triads $\left\{\alpha_{21} \alpha_{22} \alpha_{23}\right\}$; Group III (psychological and pedagogical study of personal creative development $)$ includes the seventh, eighth and ninth triads $\left\{\alpha_{31} \alpha_{32} \alpha_{33}\right\}$.

The present triadic model's structure is a $3 \times 3$ equilibrium matrix. At the same time, every $\alpha_{i k}$ element of the matrix, in turn, is a quite self-dependant triadic semantic group of elements which require investigation, and are in systemic connection with other triadic groups. Thus, for example, the triad of elements $\left\{\alpha_{11} \alpha_{12} \alpha_{13}\right\}$ can be analyzed from the point of view of general philosophical reflection, and constitute a special investigation subject: philosophical reflection on the problem of the creative development of the personality, etc.

The right column of the triadic model (a conceptual level) represents the system of statements revealing certain aspects of the problem of personal creative development relatively a corresponding element presented in the left column of the model (a categorical level). For example, ontology of creativity is presented by the following triad of statements: creativity as constructing, as an increase in being, as personal development, etc. At the same time, these statements (the right column of the model) represent project positions of integrated formation of creative and developed personality, that of a person-creator able to create the good, the sublime, the beautiful.

Thus, this model is a systemically ordered set where each element of the system is, on the one hand, an individual research area (a special subject for research) of the problem of personal creative development, while, on the other hand, taking into account the fundamental provisions of the systematic approach of P.K. Anokhin [28], B.G. Ananyev [3] and B.F. Lomov [29], is an integral (systemic) research field which combines the following research directions: (1) philosophical direction (science on being, theory of values, theory of cognition); (2) moral philosophy (ethics), theory of arts (esthetics), and history of culture; (3) psychological and pedagogical direction (psychology, pedagogy, characterology of creativity).

\section{B. Description of systemic subproblems resulting from triadic model of creative development of personality}

Note that the limited volume of this article does not allow us to describe the presented model in full, therefore we will single out here only the most essential, in our opinion, subsystems (the correspondent subsets of systemic elements).

1) Ontology, axiology and epistemology of creative development of personality

In the ontological sense, creativity is the construction of such orders of being as the good, the sublime, the beautiful. Creativity as the constructing signifies an increment of the indicated orders of being, thereby providing creative (spiritual) development of personality in seeking love, truth and love. According to A.F. Losev [26], creativity exists only in process, action, development, so personal creative development is possible only when the personality actively participates in creative, meaningful, cognitive activity. Outside of creative activities, without universal sense of seeking perfection (the good, the sublime, the beautiful), with limited (narrowed) cognitive horizons and achievements of a person, there is neither creativity, nor personal development, nor personality at all. This kind of activity in the field of education will signify just training for an individual without personal creative development.

\section{2) Ethics of development}

At the end of the 30 s of the $20^{\text {th }}$ century, N.A. Berdyaev [30] presented his outstanding discovery - paradoxical ethics of creativity, ethics of freedom, compassion and creativity - in his book "On purpose of man". It is in the ethics of creativity that Berdyaev sees the overcoming of the main tragedy of 
creativity which consists in the fact that creativity itself "wants eternity", but is forced to create the temporary and perishable things, "culture in time". According to N.A. Berdyaev [30], the way of overcoming this contradiction is through the ethics of creativity, and the real creativity of love which cannot exist otherwise than through filling a creative soul with transcendent energies of being (divine light). According to S.V. Chernov [21], the ethics of creativity should be understood as creation, cultivation, an increase in love and kindness, as transformation of evil into good, this, is fact, being the destination and sense of human being.

TABLE I. Triadic Model of CREATIVE DEVElopMent OF PERSONALITY

\begin{tabular}{|c|c|}
\hline \multicolumn{2}{|c|}{ I. General philosophical reflection on problem of creative development of personality } \\
\hline \multicolumn{2}{|r|}{ First triad (ontological) } \\
\hline $\begin{array}{l}\text { Ontology of creativity } \\
(\alpha 12)\end{array}$ & $\begin{array}{l}\text { creativity as construction } \\
\text { creativity as an increase in being } \\
\text { creativity as development of personality }\end{array}$ \\
\hline \multicolumn{2}{|r|}{ Second triad (axiological) } \\
\hline $\begin{array}{l}\text { Axiology of creativity } \\
\qquad(\alpha 12)\end{array}$ & $\begin{array}{l}\text { creativity as meaning of being of personality } \\
\text { value attributes of creativity } \\
\text { general (religious) meaning of creativity }\end{array}$ \\
\hline \multicolumn{2}{|r|}{ Third triad (epistemological) } \\
\hline $\begin{array}{l}\text { Epistemology of creativity } \\
\qquad(\alpha 13)\end{array}$ & $\begin{array}{l}\text { creativity as learning of a new, previously unknown } \\
\text { cognitive attributes of creativity } \\
\text { cognitive dialectics of creative act }\end{array}$ \\
\hline \multicolumn{2}{|c|}{ II. Ethic and esthetic, cultural and historic analysis of problem of creative development of personality } \\
\hline \multicolumn{2}{|r|}{ Fourth triad (ethic) } \\
\hline $\begin{array}{l}\text { Ethics of creativity } \\
\qquad(\alpha 21)\end{array}$ & $\begin{array}{l}\text { creativity as an increase in love and good, as transformation of evil into good } \\
\text { creativity as an increase in morality in human being } \\
\text { creativity as moral development of personality }\end{array}$ \\
\hline \multicolumn{2}{|r|}{ Fifth triad (esthetic) } \\
\hline $\begin{array}{l}\text { Esthetics of creativity } \\
\qquad(\alpha 22)\end{array}$ & $\begin{array}{l}\text { ontological sense of creating beauty } \\
\text { creativity as an increase in beauty in human being } \\
\text { creativity as artistic and esthetic development of personality }\end{array}$ \\
\hline \multicolumn{2}{|r|}{ Sixth triad (cultural and historic) } \\
\hline $\begin{array}{l}\text { Cultural and historic aspects of creativity } \\
\qquad(\alpha 31)\end{array}$ & $\begin{array}{l}\text { beginning of creativity in human history } \\
\text { cultural and historic significance of creativity in human being } \\
\text { sense of creativity in a cultural and historic perspective }\end{array}$ \\
\hline \multicolumn{2}{|c|}{ ШI. Psychological and pedagogical studies of creative development of personality } \\
\hline \multicolumn{2}{|r|}{ Seventh triad (psychological) } \\
\hline $\begin{array}{l}\text { Psychology of creativity } \\
(\alpha 31)\end{array}$ & $\begin{array}{l}\text { development of creative thinking } \\
\text { development of creative abilities } \\
\text { psychological patterns of personal organization of creative activities }\end{array}$ \\
\hline \multicolumn{2}{|r|}{ Eighth triad (pedagogical) } \\
\hline $\begin{array}{l}\text { Pedagogy of creativity } \\
(\alpha 32)\end{array}$ & $\begin{array}{l}\text { spiritual and moral education of a person-creator } \\
\text { pedagogical conditions for educating a person-creator } \\
\text { age and acmeological aspects of personal development of personality }\end{array}$ \\
\hline \multicolumn{2}{|r|}{ Ninth triad (individual and typological) } \\
\hline Characterology of creativity ( $\alpha 33$ ) & $\begin{array}{l}\text { individual and psychological characteristics of creative development of personality } \\
\text { immanent and transcendental uniqueness of creative acts } \\
\text { typology of creative personality }\end{array}$ \\
\hline
\end{tabular}

If we formulate the paradoxical ethics of N.A. Berdyaev [30] in the form and the sense of a principal statement for the system of humanitarian knowledge, then this principle can be expressed as follows: creativity as constructing must be morally justified in its foundations, beginnings and ends. Violation of this principle, which modernity often sins (for example, in postmodern art), leads to so-called "creative delights"), which cannot cause in a spiritually sensitive person nothing more than a frank sense of disgust and nausea.

The question arises: whether the system of digital education, ultimately impoverished in terms of subject-subject relations and actually devoid of possibility of direct spiritual and moral impact of a personality on another personality, can 
create a morally good atmosphere necessary to realize the ethical and creative principle formulated above.

The authors believe that answers to this crucial question can be found in modeling and conducting relevant interdisciplinary researches in the field of creativity ethics.

\section{3) Upbringing a creative person}

The participation of a person in a creative activity, product of which are ideas, subjects and objects, in which being is transformed in the form-content orders of the good, the sublime, the beautiful, contributes to a value and spiritual growth, educates not just an active individual, but forms a creative person, i.e. the personality whose all thoughts, aims and actions are directed to a spiritual transformation of being in terms of Love, Truth, Beauty.

Upbringing which is understood here as a personal assimilation of universal human, spiritual values is thought in general as very problematic in the system of digital education (at least, in the present form), since many universal human spiritual qualities, e.g. intelligence, are transmitted through generations in a traditional way, on personal examples exclusively. Therefore, modernity represents a catastrophic decrease in morality and spiritually moral poorness of a modern person-consumer. The Spanish philosopher Jose Ortega y Gasset [31] paid attention to this fact as early as in 30 s of the last century, since he told about the "cult of the body" as a sign of youth, and the "cult of the spirit" as a sign of wise maturity, at the same time noting the onset of the "era of childishness" and the "era of mass barbarism".

The modern researcher R.E. Liljeberg [32] considers the modern era as a specific carnival, as a hedonistic era of mass consumption of impressions and entertainments which, in fact, impede creative labor activities of a modern person (with the accumulation of the correspondent critical mass). As a result, a modern person becomes intellectually passive, lazy, morally ignorant. Information and digital technologies play a significant role in the expansion of these tendencies, including those in the system of modern education. That is why the idea of N.A. Berdyaev [30] about the upbringing of a creative person as a main problem of modern era is so relevant nowadays as it was never before. In our opinion, this problem must now become a key problem of practical morality, scientific pedagogy, and the ideal for developing social relations. Otherwise, speaking metaphorically, a future person will have to "climb up the tree, from which he has once climbed down".

4) Psychological and pedagogic subsystem of creative development of personality

According to D.B. Bogoyavlenskaya [33], one of the most popular areas of studies on creative development of personality is the studies on creative abilities of personality, in the structure of which intellectual, emotional and behavioral components can be distinguished. These aspects of the psychological and pedagogic approach revealing main patterns of personal creative development are acquiring a predominant character, and due to this they fall under the pattern discovered by W.R. Ashby [34] in the field of cybernetics: if "the whole system is composed of a number of subsystems, the one that seeks to dominate is the least stable". In fact, modern psychological and pedagogic researches into creativity, which are the most massive in this field, have focused on the collection and systematization of individual and narrowly specific facts, but frequently they ignore the general. Therefore, in this field focusing on facts accumulation, we can hardly expect any crucial discoveries, without profound theoretical generalizations and radical methodological transformations.

Another very popular area in the field of psychology of creativity is connected with researches into the development of creative thinking and its main patterns. Most of researches into creative thinking is conducted using the model of solving puzzle problems of D.B. Bogoyavlenskaya [33] which reflects only one, very specific, aspect of the development of creative thinking. In this respect, the researches of G.S. Altshuller [35] seem to be very promising as they are based on forming a creative personality by means of solving quite complex problems associated with subject technical constructing. Unfortunately, this area did not get its further development due to opportunistic reasons.

L.L. Alekseeva [36] notes that creative activity is not possible in the following cases: (1) when there is an instructing course which a student must follow; (2) when a student must choose from the proposed; (3) when the student must perform specified actions during the educational process.

In the conditions under which an active user of information technologies is placed today, instructions, a choice from the proposed, and specified actions are key moments of the actual functioning of any technology. Thus, the technologized system of digital education has initially been aimed at non-creative development of an individual; this system in its present form does not provide but, on the contrary, impede, in a certain sense, creative development of an individual.

\section{RESULTS}

1) In this research creativity is considered not just as the creation of something new, still unknown, but, first of all, as a spiritually and morally justified creation of the good, the sublime, the beautiful, as a process and activity of a creative person transforming being into the universal ideas of Love, Truth, Beauty.

2) The triadic model of the problem of personal creative development most fully and methodologically correctly describes individual aspects of the object under consideration, at the same time integrating them into a single triadic structured system. This model reveals sense, structure, contents of the concept of personal creative development and allows them to be explicated to the conditions of digital education. In addition, the system of statements (the right column of the model) which quite fully describes the research object represents specific project positions of the integrated formation of a creatively developed person, a creative personality capable (consciously, spiritually and morally ready) to create the good, the sublime, the beautiful.

3) Digital education (in its present form) does not have the effect of "infecting" with creativity [37], which the student receives from teachers, educators, mentors, scientific supervisors. What can fill this gap in the system of digital education and in what way? This crucial problem has not been solved yet.

4) The ultimately technologized environment of digital 
education does not leave a person involved in it a place for active creative activities and inevitably leads to a decrease in the spiritual order of being, and, as a sad result, degradation and destruction of the personality.

5) Today, the existing form of the system of digital education and the way in which it is proposed to students which have to deal with information assimilation instead of knowledge mastering, do not contribute to personal creative development but significantly decrease the spiritual order of being of an individual, taking away every possibility to become, develop, be educated as a creative, spiritually moral, creatively acting and cognizing personality.

6) Key synergic foundations which are now so lacking in modern researches on personal creative development have been identified. They, first of all, include: (1) expansion of the range of research in the field of epistemological, axiological, ontological foundations of human creative development, searches, and activities; (2) the problem of moral justification of creativity (the ethics of creativity), where creative activities of a person is inextricably associated with his spiritual and moral functions; (3) nowadays the first and principal condition is the upbringing of a creative person capable (consciously, spiritually and morally ready) to create the good, the sublime, the beautiful. Introduction of all indicated factors into the system of modern education (both traditional and digital) can become the decisive factor in the spiritual and moral recovery of our present society which is gradually being sucked into the bourgeois-consumer abyss of spiritual meon (nothing).

\section{CONCLUSION}

Scientific relevance of the research:

1) the triadic model of the problem of personal creative development has been worked out and described which presents a systemic and ordered set, where every element of the system is a whole research area (subsystem) of the problem of creative development of personality, and, on the other hand, this model is an integrated (systemic) research field combining the following research areas:

- philosophical area (doctrine on being, theory of values, cognition theory);

- moral philosophy (ethics), arts theory (esthetics) and history of culture;

- psychological and pedagogical area (psychology, pedagogy and characterology of creativity);

2) project positions of the holistic formation of a creatively developed personality capable (consciously, spiritually and morally ready) to create the good, the sublime, the beautiful, thereby increasing the order of being and multiplying its spiritual contents have been presented;

3) original concepts such as creativity, creative activity, creative development of personality have been introduced and determined;

4) conceptual principal foundations of the problem of education of a creative person have been formulated.

Modern education, at any level, cannot be exclusively digital. In modern conditions, a complete transition to digital education and a massive rejection of traditional forms of education will not only hurt the creative development of a person, but also can lead to catastrophic consequences, both in social and economic fields of society, and in the field of national security of the state.

Educational digitalization is possible only in strictly limited and scientifically determined narrow fields of educational activities, intuitively and hypothetically estimated at about no more than $15 \%$ in total, including contents, time, organization, and environment of the entire modern educational system.

Under the conditions of dehumanization and depersonalization which result directly from the technologized educational digitalization, education as the system aimed, primarily, at educating, upbringing, developing the personality, i.e., forming a spiritually moral and providentially creative IMAGE of a person, can lose its main functionality, first of all, in the field of forming higher psychic functions of the personality and the personality's spiritual sphere. As a result, education can lose its value characteristic: firstly, a personal value, then a social value, and, at last, a state value. A sad result of this may be the weakening of the national security of the state.

\section{References}

[1] N.A. Berdyaev, Spirit and Reality [Dukh i real'nost'], Moscow: AST; Kharkiv: Folio, 2006, 679 p. (In Russ.).

[2] N.A. Berdyaev, Dialectics of the Divine and the Human [Dialektika bozhestvennogo i chelovecheskogo], Moscow: AST; Kharkiv: Folio, 2005, 620 p. (In Russ.)

[3] B.G. Ananiev, Man as a subject of knowledge [Chelovek kak predmet poznaniya], $3^{\text {rd }}$ ed., Moscow [and others]: Piter, 2010, 282 p. (In Russ.).

[4] P.Ya. Galperin, Psychology lectures [Lektsii po psikhologii], Moscow: Publishing house of KDU, 2011, 400 p. (In Russ.).

[5] V.N. Markov, and Yu.V. Sinyagin, "Personality potential" ["Potentsial lichnosti”], World of Psychology [Mir Psikhologii], 2000, vol. 1(21), p. 250-261. (In Russ.)

[6] S.V. Velichko, "Role of personal potential in processes of social readaptation" ["Rol' lichnostnogo potentsiala v protsessakh sotsial'noy readaptatsii'], Advanced information technologies and intelligent systems [Perspektivnyye informatsionnyye tekhnologii i intellektual'nyye sistemy], 2004, vol. 1(17), pp. 126-130. (In Russ.).

[7] A.A. Rean, Personality adaptation psychology [Psikhologia adaptatsii lichnosti], Saint Petersburg: Praym-Euroznak, 2006, 479 p. (In Russ.).

[8] A.H. Maslow, The Farther Reaches of Human Nature, New-York, Viking Press, 1971, 456 p.

[9] C.R. Rogers, Humanistic psychology: theory and practice [Gumanisticheskaya psikhologia. Teoriya i praktika], Moscow: MPSU; Voronezh: Modek, 2013, 450 p. (In Russ.).

[10] M. Basadur, M.A. Runco, and L.A. Vega, "Understanding How Creative Thinking Skills, Attitudes and Behaviors Work Together: A Causal Process Model", The Journal of Creative Behavior, 2000, vol. 34(2), pp. 77-100. DOI: 10.1002/j.2162-6057.2000.tb01203.x

[11] T. Dewett, "Exploring the Role of Risk in Employee Creativity", Journal of Creative Behavior, 2006, vol. 40(1), pp. 27-45.

[12] G.A. Parker, "Assessment strategy and the evolution of fighting behaviour", Journal of Theoretical Biology, 1974, vol. 47(1), pp. 223243. DOI: https://doi.org/10.1016/0022-5193(74)90111-8

[13] Federal Law of December 29, 2012 No. 273-FZ "On Education in the Russian Federation”, Russian newspaper [Rossiyskaya gazeta], vol. 303, December 31, 2012. (In Russ.).

[14] M.S. Yanitsky, "Psychological aspects of digital education", Professional Education in Russia and Abroad, 2019, vol. 2(34), p. 38-42. (In Russ.).

[15] E. Toffler, Future Shock, New-York: Random House, 1970, 505 p.

[16] T.V. Semenovskikh, "Clip thinking - a modern phenomenon" ["Klipovoye myshleniye - fenomen sovremennosti"], Optimal Communication [Optimal'nye kommunikatsii], 2013. (In Russ.). Retrieved from http://jarki.ru/wpress/ 2013/02/18/3208/ 
[17] E.P. Kabkova, and V.S. Meshcheryakova, "The development of creative abilities. Another formulation of the question", in Proceedings of RSPC on Problems of creative development of personality in education system [Problemy tvorcheskogo razvitiya lichnosti v sisteme obrazonaniya], 2019, pp. 35-41. (In Russ.).

[18] N.V. Borisova, "Digital society through the prism of heritage of S.L. Rubinstein", in Proceedings of ISRC on Digital society in cultural and historical paradigm [Tsifrovoye obshchestvo v kul'turno-istoricheskoy paradigme], 2018, p. 132-136. (In Russ.).

[19] A.V. Karpov, Labor psychology [Psikhologiya truda]: a textbook for universities, Moscow, 2004. (In Russ.).

[20] N.A. Berdyaev, "The Problem of Man (Towards the Construction of a Christian anthropology)", Put', 1936, vol. 50, pp. 3-26. Retrieved from http://www.berdyaev.com/berdiaev/berd_lib/1936_408.html

[21] S.V. Chernov, "On creative purpose of man" ["O tvorcheskom naznachenii cheloveka"], Philosophy and Culture, 2011, vol. 1(37), pp. 41-49. (In Russ.).

[22] L.I. Bozhovich, Problem of development of motivational sphere of child [Problema razvitiya motivatsionnoy sfery rebenka], In Study of motivation of children and adolescents [Izucheniye motivatsii detey $\mathrm{i}$ podrostkov], 1972, p. 7-44. (In Russ.).

[23] I. Kant, Critique of Pure Reason, Cambridge University Press, 2013. Retrieved from https://www.cambridge.org/core/books/critique-of-purereason/259C2355B74458963EC285F53337AAF0

[24] G.W.F. Hegel, Science of Logic, Cambridge University Press, 2010, 863 p. Retrieved from https://stradnieki.org/files/Science_of_Logic.pdf

[25] V.S. Soloviev, Works in 2 Volumes, Moscow: Mysl', 1990. (In Russ.).

[26] A.F. Losev, "Dialectics of the Creative Act (Short Sketch)" ["Dialektika tvorcheskogo akta (Kratkiy ocherk)“], Kontekst-1981, 1982, vol. 1981, pp. 48-78. (In Russ.).

[27] S.V. Chernov, "Triadic dialectics of genius", Philosophical School [Filosofskaya shkola], 2018, vol. 6, p. 61-73. (In Russ.). DOI: $10.24411 / 2541-7673-2018-10643$
[28] P.K. Anokhin, Essays on physiology of functional systems [Ocherki po fiziologii funktsional'nykh system], Moscow, 2013, 450 p. (In Russ.).

[29] B.F. Lomov, Systematic in Psychology: Selected Psychological Works [Sistemnost' v psikhologii: izbrannyye psikhologicheskiye trudy], $3^{\text {rd }}$ edition, Moscow: Publishing house of Moscow Psychological Social Institute; Voronezh: MODEK, 2011, 423 p. (In Russ.).

[30] N.A. Berdyaev, The Destiny of Man. Slavery and Freedom [O naznachenii cheloveka. O rabstve i svobode cheloveka], Moscow: AST, 2006, 637 p. (In Russ.)

[31] J. Ortega y Gasset, The Revolt of the Masses, 1930. Retrieved from http://pinkmonkey.com/dl/library1/revolt.pdf

[32] R.E. Liljeberg, "Carnival's children” phenomenon as a result of intergeneral broadcast and reproduction of carnival forms of mass culture", Philosophical School [Filosofskaya shkola], 2019, vol. 7, pp. 30-49. (In Russ.).

[33] D.B. Bogoyavlenskaya, "Creative personality development in the education system (when taking into account the forms of mastering the activity)", In Proceedings of RSPC on Problems of creative personality development in education system, 2019, pp. 8-17. (In Russ.).

[34] W.R. Ashby, Design for a brain: The origin of adaptive behaviour, New York, $1960, \quad 304 \quad$ p. $\quad$ Retrieved from https://archive.org/details/designforbrainor00ashb/page/n5/mode/2up

[35] G.S. Altshuller, To Find an idea. Introduction to TRIZ - theory of inventive problem solving, Moscow: Alpina Publisher, 2017, 404 p. (In Russ.).

[36] L.L. Alekseeva, "Creativity and its analogues in modern art education", In Proceedings of RSPC on Problems of creative personality development in education system, 2019, pp. 18-25. (In Russ.).

[37] Ya.I. Ivanova, "Effect of "infection" by creativity. Publishing activity of public libraries as a factor in creative development of staff" [Effekt "zarazheniya" tvorchestvom. Izdatel'skaya deyatel'nost' bibliotek kak faktor tvorcheskogo razvitiya personala], Library Science [Bibliotechnoye delo], 2008, vol. 2(68), pp. 10-12. (In Russ.). 